\title{
Стан управління ризиками при наданні стоматологічної допомоги
}

\author{
А.Г. Круть \\ Національний університет охорони здоров'я України імені П.Л. Шупика, Київ, Україна
}

Анотація. Мета: дослідити стан управління ризиками при наданні стоматологічної допомоги в сертифікованих системах управління якістю та запропонувати напрями його удосконалення. Об'єкт дослідження: сертифіковані системи управління якістю закладів стоматологічного профілю. Предмет дослідження: заходи з управління ризиками; внутрішні документи профільних закладів охорони здоров'я - комунальних некомерційних підприємств: «Житомирське обласне стоматологічне медичне об'єднання»; «Обласна стоматологічна поліклініка Харківської обласної ради»; «Чернігівська обласна стоматологічна поліклініка Чернігівської обласної ради», усього 34. Методи дослідження: системного підходу, порівняльного і логіко-структурного аналізу, контент-аналізу, графічний. Результати. Показано, що нечітка термінологія стандарту у визначенні поняття «ризик» призводить до труднощів при ідентифікації ризиків. Перелік ризиків внутрішнього середовища відокремлений від процесів медичної допомоги, забезпечення ресурсами, менеджменту. Цим створюються ризики недоврахування ризикових подій; відсутнє планування заходів з управління ними. До ідентифікації та заходів з попередження реалізації ризиків залучається обмежене коло працівників, що стає перепоною для поширення ризикорієнтованого мислення. Відсутні доказові технології стоматологічної допомоги, що зумовлює високі ризики результативності клінічного процесу. Це підтверджено випадками незадоволеності і скарг пацієнтів, ускладнень медичних процедур. Висновки. Напрями удосконалення управління ризиками при наданні стоматологічної допомоги в сертифікованих системах управління якістю полягають у постійному навчанні керівників закладів вимогам ДСТУ ISO 9001:2015, ідентифікації ризиків відповідно до процесів, поширенні ризикорієнтованого мислення, запровадженні доказових медичних технологій.

Ключові слова: ідентифікація ризиків, ризикорієнтоване мислення, процеси, доказові медичні технології, менеджмент.

\section{Вступ}

В основу тенденцій розвитку сучасного менеджменту організацій будь-якої сфери діяльності покладається, зокрема, здатність керівників управляти ризиками. Уміле й компетентне прийняття адекватних управлінських рішень за умов впливу різноманітних ризиків убезпечує організацію від перешкод на шляху до досягнення визначених цілей і позитивно позначається на результатах діяльності та конкурентоспроможності організації на ринку.

Особливої актуальності це питання набуває у сфері охорони здоров'я, оскільки для сучасної медицини характерне запровадження більш інноваційних, але складних технологій діагностики та лікування, ніж на початку століття. Одночасно це зумовлює не лише можливості для покращення результатів медичної допомоги й задоволення очікувань зростаючих вимог пацієнтів, але й підвищення ризиків нанесення їм шкоди.

Визнаючи, що певний рівень шкоди неминучий, дослідники вважають, що своєчасне розпізнавання ризиків та розробка активних стратегій управління ними $\epsilon$ шляхом до безпечнішої медичної допомоги [1].

Об'єктами управління ризиками, або ризик-менеджменту, визначені різноманітні ризики за своїм походженням, зокрема, політичні, правові, соціально-економічні, корпоративні та інші, які чинять вплив на функціонування закладів охорони здоров'я. Окрім того, специфічними ризиками для сфери охорони здоров'я $\epsilon$ ризики, пов'язані з безпосереднім наданням медичної допомоги, тобто ризики лікувально-діагностичного процесу, які в науковій літературі називають клінічними ризиками. Ці ризики створюють серйозні негативні наслідки для безпеки пацієнтів та стають причинами зростання фінансових витрат для провайдерів медичних послуг [2, 3].

Велика увага дослідників щодо ризиків в охороні здоров'я спрямована також на інфекції, пов'язані з медичною допомогою, навчання медичних працівників з питань протидії ризикам, аналіз організаційних моделей безпеки в охороні здоров'я [4].

Одна з таких управлінських моделей пропонується в рамках системи менеджменту якості закладу охорони здоров'я, сертифікованої на відповідність вимогам стандарту [5]. Обов'язкова сертифікація $\epsilon$ нормативною умовою отримання закладом охорони здоров'я вищої акредитаційної категорії.

Вимоги стандарту стосовно ризиків представлено в його наступних розділах/підрозділах (в адаптації для медичних організацій):
- 4.1 «Розуміння організації та її середовища»: закладу необхідно визначити ризики, які можуть вплинути на його здатність досягати цілей системи із забезпечення якості медичної допомоги;

- 5 «Лідерство», 5.1.1 «Загальні положення»: найвище керівництво повинне демонструвати своє лідерство та своє зобов'язання щодо системи управління якістю шляхом, зокрема, ризикорієнтованого мислення;

- 6.1 «Дії стосовно ризиків і можливостей», 6.1.1: під час планування в системі управління якістю організація повинна розглянути чинники, зазначені в 4.1; 6.1.2: заклад повинен планувати дії стосовно цих ризиків і можливостей;

- 8.1 «Оперативне планування та контроль»: заклад повинен планувати, запроваджувати та контролювати процеси, потрібні для задоволення вимог з надання послуг, а такождля виконання дій, визначених у розділі 6;

- 9.1.3 «Аналізування та оцінювання»: заклад повинен оцінювати результативність дій, виконаних щодо ризиків і можливостей;

- 10.2 «Невідповідність і коригувальні дії»: за потреби необхідно оновлювати ризики та можливості, визначені під час планування.

Вітчизняних досліджень з управління ризиками в сертифікованій системі управління якістю медичної допомоги практично не проводилося, що посилює актуальність дослідження.

Мета: дослідити стан управління ризиками в сертифікованих системах управління якістю закладів охорони здоров'я (на прикладі закладів третинної медичної допомоги стоматологічного профілю) та запропонувати напрями його удосконалення.

\section{0б'єкт і методи дослідження}

06'єктами дослідження слугували системи управління якістю закладів третинної медичної допомоги стоматологічного профілю, обраних базою дослідження.

Предмет дослідження: заходи з управління ризиками, які використовуються керівниками закладів; плани роботи закладів; плани і графіки навчання персоналу; положення про структурні підрозділи; положення про позаштатні організаційні структури; посадові інструкції працівників, накази, протоколи, методики, інструкції тощо, усього 34. Базою дослідження обрані комунальні некомерційні підприємства (КНП) - «Житомирське обласне 
стоматологічне медичне об'єднання»; «Обласна стоматологічна поліклініка Харківської обласної ради»; «Чернігівська обласна стоматологічна поліклініка Чернігівської обласної ради».

Методи дослідження: системного підходу, порівняльного і логіко-структурного аналізу, контент-аналізу, графічний.

Дослідження проводили за даними періоду 2010-2019 рр.

\section{Результати та їх обговорення}

Установлено, що на виконання вимог п. 4.1 стандарту в досліджуваних закладах визначені потенційні ризики, які можуть вплинути на здатність досягти очікуваних результатів при наданні стоматологічної допомоги пацієнтам. Заклади, як вимагає стандарт, розподілили їх на ризики зовнішнього та внутрішнього середовища.

У матеріалах дослідження КНП «Житомирське обласне стоматологічне медичне об'єднання» перелік сукупних ризиків наступний:

1) аналіз змін в законодавстві стосовно закладів охорони здоров'я;

2) результати опитування пацієнтів і персоналу;

3) результати виконання щорічного комплексного плану заходів;

4) результати внутрішніх аудитів та коригувальних дій.

Слід зазначити, що ризиками, за термінологією стандарту, $\epsilon$ вплив невизначеності на досягнення цілей, а отже ризик - це подія, яка може трапитися, але ще не відбулася. Тому результати опитувань, виконання планів, внутрішніх аудитів свідчать вже про реалізовані ризики (позитивні або негативні), тому їх не можна представляти як потенційні.

У КНП «Обласна стоматологічна поліклініка Харківської обласної ради» ризиками зовнішнього середовища визначені:

1) зростання вимог до послуг з боку пацієнтів;

2) терміни постачанняпродуктівіпослугвідзовнішніхпостачальників; наявність і кількість, виробничі потужності постачальників; виконання постачальниками умов договорів;

3) політична та економічна ситуація в країні (щорічна інфляція, воєнні події);

4) недосконалість законодавства (суперечливість, відсутність гармонізації з міжнародними нормами);

5) насиченість ринку аналогічними медичними послугами, інновації в галузі, технічне оснащення конкурентів;

6) природні фактори (погодні явища - дощі, зливи, які можуть бути причинами порушень подачі електроенергії).

Ризиками внутрішнього середовища у даному закладі вважають:

1) укомплектованість персоналом; компетентність і продуктивність роботи персоналу; сумлінність при виконанні вимог; мотивація, взаємини в колективі; лояльність до закладу;

2) достатність і потужність, частота поломок медичного обладнання, наявність запасних частин, швидкість їх доставки у разі виходу з ладу;

3) достатня кількість і якість товарів і медичних виробів;

4) стан інфраструктури, умови праці;

5) вартість і якість комунальних послуг;

6) безпека використання обладнання й енергії, пожежна безпека.

У КНП «Чернігівська обласна стоматологічна поліклініка Чернігівської обласної ради» до зовнішніх ризиків віднесені:

1) податкова, кредитна, фінансова, інвестиційна політика держави;

2) зміни в нормативно-правовому регулюванні діяльності закладів охорони здоров'я;

3) державна система стандартизації та сертифікації;

4) правове регулювання захисту споживачів послуг;

5) ринок медичних послуг;

6) вимоги громадських і недержавних інституцій до діяльності закладів охорони здоров'я;

7) діяльність політичних партій, рухів і блоків;
8) технологічні чинники (впровадження новітніх технологій, нові вимоги до компетенцій персоналу, модернізація обладнання); соціально-культурні характеристики громади.

Ризики внутрішнього середовища визначені як «...управлінські рішення щодо досягнення запланованих результатів за напрямами: менеджмент виробництва, маркетингу, фінансів, персоналу» (цитата з матеріалів дослідження).

Змістовний аналіз наведених ризиків КНП «Обласна стоматологічна поліклініка Харківської обласної ради» та КНП «Чернігівська обласна стоматологічна поліклініка Чернігівської обласної ради» також засвідчив використання наявних перешкод у якості потенційних ризикових подій.

3 наведених переліків видно, що заклади намагалися керуватися рекомендаціями стандарту, у яких представлені приклади ризиків: зовнішнього середовища - правові, технологічні, конкурентні, ринкові, культурні, соціально-економічні; внутрішнього середовища - ризики, пов'язані з цінностями, культурою, знаннями і дієвістю організації. Кожен заклад певною мірою виконав вимоги стандарту, але вдалося це не в повній відповідності.

Справа в тому, що стандарт, крім запропонованого приблизного переліку ризиків внутрішнього середовища (в примітці), пропонує ідентифікувати їх під час планування системи управління якістю (п. 6.1.1), структура якої, в свою чергу, складається з процесів та взаємозв'язків між ними (п. 4.4). Отже, за вимогами стандарту, потрібно «вбудовувати» ризики у процеси при плануванні останніх, що вказує на тісний взаємозв'язок ризиків з процесною діяльністю. Таким чином, ідентифікація ризиків внутрішнього середовища на рівні процесів закладу (основних - медичної діяльності, допоміжних - процесів менеджменту та забезпечення ресурсами) - сприятиме їх «прив'язці» до процесів і упорядкуванню, на відміну від існуючих переліків в реальній управлінській практиці.

Як може виглядати ідентифікація ризиків внутрішнього середовища через процеси (види діяльності) в системі управління якістю, представлено в таблиці.

Приклади, наведені в таблиці, потребують деталізації на рівні кожного процесу залежно від закладу, його структурних підрозділів та виконавців процесів до ступеня, коли реалізація потенційних ризиків, якщо ї̈ не можна повністю усунути, буде мінімальною. Таким чином, насправді ризиків значно більше, ніж представлено у матеріалах досліджуваних закладів. Також стає очевидним, що до процесу ідентифікації ризиків мають бути причетні практично всі працівники закладів, оскільки погляди людей, безпосередньо задіяних у процесах, їх професіоналізм і компетентність $\epsilon$ цінним внеском у моделювання ситуацій, які можуть статися за конкретних обставин при виконанні даного виду робіт.

Такий висновок випливає також з одного з принципів управління якістю, яким передбачається широке залучення персоналу до управління якістю, що можна втілити, зокрема, через підходи до управління ризиками.

Виконання пп. 5.1.1 «Загальні положення» підкріплено письмовими зобов'язаннями найвищого керівництва кожного закладу у документі «Політика в сфері якості» щодо усвідомлення своєї відповідальності та прийняття на себе зобов'язань щодо системи управління якістю, зокрема ризикорієнтованого мислення. Останнє можливо в разі, коли керівник пропагує насторогу стосовно ризиків серед колективу, що має бути представлено у посадових інструкціях, протоколах виробничих нарад, протоколах засідань медичної ради, звітах за підсумками діяльності, однак така систематична діяльність не простежується. За умови ідентифікації ризиків у зв'язку з процесами на всіх рівнях управління закладом практично кожен працівник на своєму робочому місці повинен постійно підтримувати таку насторогу, в чому допомагатиме володіння інформацією про ризики. Даного підходу не виявлено при аналізі матеріалів дослідження.

Як наслідок, при оцінці виконання п. 6.1.2 стандарту встановлено, що при описах основних і допоміжних процесів, які формують організаційну структуру системи управління якістю, планування дій з реагування на ризики та можливості у досліджуваних закладах простежується в обмеженому обсязі. 
Таблиця Приклади можливої ідентифікації ризиків внутрішнього середовища через процеси (види діяльності) в закладі охорони здоров'я Процес Потенційні ризики

Основні процеси:

- профілактики;

- надання медичної допомоги

Ризики проєктування та розробки медичної технології (на рівні закладу — ризики при організації та розробці локальних медико-технологічних документів; на рівні лікаря — ризики при розробці персонального плану медичної допомоги конкретному пацієнту)

Ризики при наданні медичної допомоги (пов'язані з тривалістю очікування, правильністю ідентифікації пацієнта, згодою на медичне втручання; діагностичні; лікувальні; фармакотерапевтичні; інфекційні; профілактичні; організаційні при взаємодії з іншими закладами/відділеннями; пов'язані 3 харчуванням в стаціонарі; пов'язані з веденням документації процесу, інші)

Допоміжні процеси - Р Ризики, пов'язані з наявністю, кваліфікаційним рівнем і безперервним професійним розвитком персоналу

забезпечення ресурсами:

- кадровими Ризики, пов'язані з медичним обладнанням (відсутність; несправність; невідповідність; помилки при використанні, інші); пов'язані з програмним,

- інфраструктурними транспортним забезпеченням, засобами зв'язку, закупівельними матеріалами (недостатнє, невідповідне, застаріле, пошкоджене тощо)

Ризики, пов'язані з експлуатацією приміщень, конструкцій, меблів, предметів догляду (їх застарілість, зношеність, пошкодження, несправність, відсутність тощо)

- середовищем процесів Ризики: соціальні; етико-деонтологічні; психоемоційні; фізико-хімічні; гігієнічні

- знаннями, компетентністю, Ризики, пов'язані з дефіцитом та/або неправильними знаннями, відсутністю/недостатністю компетентності, обізнаності; відсутністю/недостатністю/ обізнаністю, інформацією хибністю інформації

- задокументованою Ризики, пов'язані з недостатністю, недоступністю або затримкою доступу; неясною/неоднозначною/нерозбірливою/неповною інформацією в документі інформацією

Допоміжні процеси — менедж- Ризики, пов'язані з розробкою політики і цілей, плануванням, організацією, координацією діяльності, оцінкою й аналізом функціонування системи, менту прийняттям рішень з покращення діяльності

Окремі заходи, що стосуються попередження реалізації ризиків, включені до щорічних комплексних планів діяльності, однак вони швидше відображають вимоги діючого законодавства до різних аспектів функціонування закладів охорони здоров'я, тому мають невпорядкований, фрагментарний характер і, як вже зазначалося вище, не охоплюють усі ідентифіковані процеси.

Так, у КНП «Житомирське обласне стоматологічне медичне об'єднання» до комплексного плану роботи на рік у розділ «Лікувальна справа» внесені заходи з фіксації дози опромінення при рентгенологічному обстеженні пацієнта, контролю за проведенням флюорографічного обстеження пацієнтів, які вперше звернулися за стоматологічною допомогою поточного року, використання формулярів лікарських засобів і локальних клінічних протоколів медичної допомоги.

У розділі «Зміцнення матеріально-технічної бази та покращення санітарно-гігієнічного режиму» заплановані заходи з проведення ремонтних робіт, придбання обладнання для стерилізації та збереження стерильного інструментарію, у розділі «Заходи з покращення умов праці» - проведення інструктажів з охорони праці й техніки безпеки.

У КНП «Обласна стоматологічна поліклініка Харківської обласної ради» в розділі «Робота з кадрами» заплановано заходи 3 проведення щорічних профілактичних оглядів медичних працівників і обстеження окремих контингентів працівників на носійство патогенного стафілококу; в розділі «Додержання санітарно-протиепідемічного режиму» передбачено проведення занять з персоналом з питань дотримання санітарних норм і правил з дезінфекції і стерилізації медичних виробів; контролю за дотриманням санітарно-протиепідемічного режиму; метрологічного контролю медичного обладнання; ремонтних робіт окремих приміщень; заходів з протипожежної безпеки.

У КНП «Чернігівська обласна стоматологічна поліклініка Чернігівської обласної ради» плановими заходами передбачено вивчення усіх нормативних документів, які регламентують інфекційну безпеку закладу, метрологічне забезпечення, підготовку і перепідготовку кадрів, профілактику професійних захворювань; передбачено оновлення обладнання, ремонтні роботи та протипожежні заходи тощо.

Отже, серед усіх ідентифікованих ризиків найбільша увага при плануванні діяльності керівництвом закладів приділяється таким, як інфекційні, інфраструктурні, кадрові ризики, ризики, пов'язані з використанням лікарських засобів. Планові заходи щодо ризиків не охоплюють не лише перелік ризиків усіх процесів, але й не відповідають повному переліку ризиків зовнішнього і внутрішнього середовища, задекларованого закладами, що створює, у свою чергу, ризики недоврахування певного числа потенційної небезпеки і відсутність, внаслідок цього, планування заходів з їх попередження на рівні системи та процесів.
Зокрема, надзвичайно мало уваги приділяється власне клінічним ризикам залежно від патології, з якою може звернутися пацієнт, з метою запобігання виникненню небажаних ефектів або зменшенню їх кількості при наданні стоматологічної допомоги. Це підтверджено використанням в досліджуваних закладах локальних протоколів стоматологічної допомоги, ідентичних протоколам лікування стоматологічних захворювань, затверджених галузевим наказом ще в 2004 р. Ці протоколи розроблені експертним шляхом, а не на основі досягнень доказової медицини, доступних із світових наукових джерел і систематичних оглядів. Тим самим створюються ризики низької результативності надаваної медичної допомоги й неадекватного використання ресурсів.

Використання протоколів лікування стоматологічних захворювань, створених експертним шляхом, унеможливлює моніторинг клінічних ризиків, оскільки зазначені протоколи не містять клінічних критеріїв та індикаторів якості. Отже, будь-які відхилення в клінічному процесі залишаються поза увагою лікаря, завідувача відділення, медичного директора.

Контроль ризиків процесів, визначених у досліджуваних закладах, на виконання п. 8.1 стандарту, хоча й не за повним переліком, здійснюється на різних рівнях управління закладом: завідувачів структурних підрозділів, медичного директора, керівника закладу. До поточного й підсумкового контролю залучені комісія з інфекційного контролю, фармакотерапевтична комісія, групи внутрішнього аудиту, медична рада, рада медичних сестер, експертні групи.

Незважаючи на складну багаторівневу систему контролю, виявлені докази реалізації ризиків упродовж 2010-2019 рр.: незадоволеність пацієнтів КНП «Житомирське обласне стоматологічне медичне об'єднання» організацією стоматологічної допомоги та станом приміщень закладу, висловлену на офіційних вебпорталах; інформація від пацієнтів КНП «Обласна стоматологічна поліклініка Харківської обласної ради» про неодноразові ускладнення після стоматологічної допомоги на офіційному вебсайті закладу та щорічні письмові скарги на якість медичного обслуговування; більше десятка пацієнтів КНП «Чернігівська обласна стоматологічна поліклініка Чернігівської обласної ради» також звертаються щороку зі скаргами на медичне обслуговування у вищі органи управління.

Таким чином, простежується неглибокий аналіз ризиків та низька результативність реагування на їх реалізацію керівництва закладів, що свідчить про виконання неповною мірою вимог п. 9.1.3 стандарту. Виявлено переважно збереження переліку ідентифікованих ризиків у планах діяльності упродовж 2010-2019рр., епізодичне їх оновлення, що свідчить про недостатню увагу керівництва закладів до змін ризиків внутрішнього і зовнішнього середовища. Цим функції управління ризиками в реальній практиці суперечать вимогам п. 10.2 стандарту щодо перегляду ідентифікації та своєчасності реагування на ризики. 


\section{Висновки}

1. Показано, що досить складна термінологія стандарту у визначенні поняття «ризик» викликає труднощі при ідентифікації ризиків в системах управління якістю закладів стоматологічного профілю. Це призводить до нечіткого їх виокремлення й підміни поняття ризиків як потенційних подій подіями, що вже відбулися.

2. Виявлено, що в досліджуваних закладах не використовується методичний підхід, за вимогами стандарту, до ідентифікації ризиків внутрішнього середовища відповідно до видів діяльності закладів: медичної допомоги, забезпечення ресурсами, менеджменту. Тим самим складається обмежений перелік ризиків, що створює, в свою чергу, ризики недоврахування можливих негативних ризикових подій та відсутність планування заходів з управління ними.

3. Встановлено, що до ідентифікації та попередження реалізації несприятливих ризиків не залучається широке коло працівників закладів. Це заперечує виконання вимог стандарту з впровадження ризикорієнтованого мислення, основою якого $\epsilon$ правильні підходи до ідентифікації ризиків.

4. Доведено, що в закладах існують високі ризики результативності клінічного процесу, оскільки запобіжні заходи з використання доказових технологій стоматологічної допомоги не впроваджені в практику діяльності. Ці ризики знаходять своє втілення у вигляді незадоволеності пацієнтів стоматологічною допомогою, ускладнень внаслідок медичних процедур, скарг пацієнтів до вищих органів управління.

5. Напрями удосконалення управління ризиками в сертифікованих системах управління якістю при наданні стоматологічної допомоги полягають у більш активному й постійному навчанні керівників усіх рівнів управління закладами вимогам ДСTY ISO 9001:2015, ідентифікації ризиків внутрішнього середовища відповідно до процесів (видів діяльності), розповсюдження ризикорієнтованого мислення на широке коло працівників, запровадження локальних клінічних протоколів стоматологічної допомоги, розроблених на основі сучасних доказових технологій.

\section{Перспективи подальших досліджень}

Перспективи подальших досліджень полягають в оцінці результатів управління ризиками при наданні стоматологічної допомоги в сертифікованих системах управління якістю після впровадження запропонованих напрямів удосконалення.

\section{Конфлікт інтересів}

Автор заявляє про відсутність конфлікту інтересів.

\section{Список використаної літератури}

1. Amalberti R., Vincent C. (2020) Managing risk in hazardous conditions: improvisation is not enough. BMJ Qual. Saf., 29(1):60-63. doi:10.1136/bmjqs-2019-009443

\section{Відомості про автора:}

Круть Анатолій Григорович - кандидат медичних наук, доцент, директор Стоматологічного навчально-практичного медичного центру Національного університету охорони здоров'я України імені П.Л. Шупика, Київ, Україна. ORCID ID: 0000-0001-6503-3952

\section{Адреса для кореспонденції:}

Круть Анатолій Григорович

04112, Київ, вул. Дорогожицька, 9

E-mail:akrut@ukr.net
2. Messano G.A., De Bono V., Di Folco F., Marsella L.T. (2014) Past and present of risk management in healthcare. Ig. Sanita Pubbl., 70(4): 423-430.

3. Farokhzadian J., Dehghan Nayeri N., Borhani F. (2015) Assessment of Clinical Risk Management System in Hospitals: An Approach for Quality Improvement. Glob. J. Health Sci., 7(5): 294-303. doi: 10.5539/gjhs.v7n5p294

4. Odone A., Bossi E., Gaeta M. et al. (2019) Risk Management in healthcare: results from a national-level survey and scientometric analysis in Italy. Acta Biomed., 90(9-S):76-86. doi: 10.23750/ abm.v90i9-S.8164

5. Національний стандарт України (2016) ДСТУ IS0 9001:2015 (IS0 9001:2015, IDT) «Системи управління якістю. Вимоги» (https://khoda.gov.ua/image/catalog/files/\%209001.pdf).

\section{The state of risk management in dental care}

\section{A.G. Krut}

Shupyk National Healthcare University of Ukraine, Kyiv, Ukraine

Abstract. Purpose: to investigate the state of risk management in the provision of dental care in certified quality management systems and suggest areas for its improvement. Object of study: certified quality management systems for dental institutions. Subject of study: risk management activities; internal documents of specialized healthcare institutions - communal non-profit enterprises: «Zhytomyr Regional Dental Medical Association»; «Regional Dental Clinic» of the Kharkiv Regional Council; «Chernihiv Regional Dental Clinic of the Chernihiv Regional Council», 34 units in total. Research methods: systematic approach, comparative and logical-structural analysis, content analysis, graphic. Results. It is shown that the fuzzy terminology of the standard in defining the concept of risk leads to difficulties in identifying risks. The list of risks of the internal environment is separated from the activities of providing medical care, provision of resources, management. Thus, the risks of loss of risk events are created, there is no planning of measures to manage them. A limited circle of employees is involved in the identification and prevention of risks, this becomes an obstacle to the spread of risk-based thinking. There are no evidence-based technologies for dental care, which leads to high risks of the effectiveness of the clinical process. This is confirmed by cases of dissatisfaction and complaints of patients, complications of medical procedures. Conclusions. Directions for improving risk management in the provision of dental care in certified quality management systems include continuous training of facility managers with the requirements of the standard, identification of risks in accordance with processes, dissemination of risk-based thinking, and the introduction of evidence-based medical technologies.

Key words: risk identification, risk-based thinking, processes, evidence-based medical technologies, management.

\section{Information about the author:}

Krut Anatoliy G. - Candidate of Medical Sciences, Associate Professor, Director of the Dental Educational and Practical Medical Center of the Shupyk National Healthcare University of Ukraine, Kyiv, Ukraine. ORCID ID: 0000-0001-6503-3952

\section{Address for correspondence:}

Anatoliy Krut

04112, Kyiv, Dorohozhytska str., 9

E-mail:akrut@ukr.net 